\title{
Pokrajine dobivajo ustavne temelje
}

\author{
UDK: $352: 342.4$
}

Janez Šmidovnik

\section{1}

Ni pretirano reči, da pomeni sklep Ustavne komisije Državnega zbora z dne 12.4. tega leta, da predlaga Državnemu zboru "kompromisno besedilo" političnih strank za začetek postopka za spremembo 121., 140. in 143. člena ustave, ki ga je s svojimi podpisi podprlo 72 poslancev Državnega zbora, pravi zgodovinski premik $v$ razvoju države Slovenije in njene lokalne samouprave. Taka ugotovitev je upravičena iz več razlogov:

1. ker je razprava o pokrajinah, ki se jih tiče ta predlog, bolj ali manj intenzivno trajala ves čas po vzpostavitvi občin v letu 1994 - to je dobrih dvanajst let - in je bil prvi predlog za spremembo 143. člena ustave vložen $\vee$ Državnem zboru že leta 1999 (to je predlog 33 poslancev z dr. Ribičičem na čelu), drugi predlog za spremembo vseh navedenih treh členov leta 2001 (to je predlog vlade skupaj z drugimi predlogi $\vee$ prejšnjem ustavno-revizijskem postopku) in tretji predlog poslanske skupine LDS v letu 2005 (to je predlog skupine poslancev s prvopodpisano Darjo Lavtižar Bebler);

2. ker je šlo $v$ razpravah o teh predlogih za velika razhajanja, lahko bi rekli za diametralno nasprotna stališča glede tega, kaj je treba storiti glede pokrajin oziroma glede t.i. regionalizacije Slovenije in se ta razhajanja niso zbliževala;

3. ker gre pri navedenem predlogu za sprožitev postopka za spremembo ustave za odločitev, ki bo povzročila, če oziroma ko bo sprejeta, pomembne preureditve znotraj obstoječega sistema lokalne samouprave, pa tudi znotraj vsega državnega mehanizma države Slovenije.

Vse do pred kratkim se je zdelo, da obstoje skoraj nepremostljive razlike med stališči glede tega, ali za ustanovitev pokrajin sploh potrebujemo kakšno spremembo v ustavi, če pa že, kakšne naj bi bile te spremembe. Ob vsem tem je treba poudariti, da se na glas nihče ni izjavljal proti pokrajinam, čeprav ni bilo težko domnevati, da so se med "ustavobranitelji veljavne ustave dejansko 


\section{Janez Šmidovnik}

\section{Pokrajine dobivajo ustavne temelje}

skrivali prav tisti, ki so bili v resnici proti regionalizaciji Slovenije na pokrajine, ali pa so si pokrajine predstavljali le kot nekakšne podaljške občin.

Kot je očitno, govorim o razlikah, ki so se pojavljale na nivoju politike. $V$ stroki je bilo sicer $v$ začetku nekaj glasov o tem, da bi se morda dalo na kak način priti do pokrajin tudi na podlagi sedanje formulacije 143. člena ustave. Vendar so ti glasovi utihnili, ko je tudi praksa ob poskusih za pripravo zakona o pokrajinah, pa tudi spričo konkretnih sklepov posameznih občinskih svetov o ustanovitvi pokrajin na nekaterih območjih Slovenije, pokazala, da na veljavni ustavni osnovi, to je "s samostojnim odločanjem o povezovanju občin v širše samoupravne lokalne skupnosti«, kakor je rečeno $v$ uvodni formulaciji 143. člena ustave, ni mogoče priti do pokrajin, vsaj ne takih s statusom samoupravne lokalne skupnosti, ki bi jim bilo zagotovljeno samostojno delovanje - podobno kot občinam. Ne le $v$ teoriji, tudi v praksi se je pokazalo, da zgolj s povezovanjem občin pokrajine ne morejo nastati in tudi ne dobiti statusa samoupravnih lokalnih skupnosti z elementi samoupravnosti (funkcionalne, teritorialne, organizacijske, materialno-finančne in pravne), ki so vsebina tega statusa. Z medobčinskim povezovanjem je mogoče zajeti le sosednje občine in le glede posameznih vprašanj, ki zanimajo te občine. Pokrajine pa morajo pokriti vso državo - tako kot občine; imeti morajo isti pravni status in iste naloge $v$ vsej državi, sicer bi prišlo do vsesplošnega kaosa. Tak status jim lahko zagotovi le država z ustavo in z zakonom, kakor ga je zagotovila občinam z ustavo in z Zakonom o lokalni samoupravi.

To pomeni, da je treba spremeniti ustavo, če hočemo dobiti pokrajine. Da brez spremembe ustave pokrajin ne bo, sem zapisal še pred sprejemom ustave $v$ takratnih Naših razgledih, ko me je $v$ končnem osnutku ustave presenetila obstoječa formulacija 143. člena, ki je nastala $\vee$ zadnjem trenutku pred sprejemom ustave. Takrat mi je bilo rečeno, da je formulacija 143. člena kompromisna politična rešitev, ki je omogočila, da smo dobili $v$ ustavo 55. člen o svobodnem odločanju o rojstvu otrok, ki dopušča tudi splav. Bliže resnici pa je, da je bila kontradiktorna formulacija 143. člena kompromis med tistimi, ki so bili za močno decentralizacijo države na lokalno samoupravo in med centralisti, ki so bili za centralno upravljanje Slovenije s šibko decentralizacijo na lokalne skupnosti, ker so se bali, da bi te skupnosti utegnile dezintegrirati državo Slovenijo, še preden bi se ta utrdila kot čvrsta državna skupnost. Formulacija 143. člena je na videz ustregla obojim: tistim, ki so bili za močnejšo decentralizacijo države - z obljubo o dvostopni lokalni samoupravi oziroma o regionalizaciji države Slovenije na pokrajine, centralistom pa z določbami o svobodnem povezovanju občin $v$ pokrajine, $\mathrm{ki}$ je zagotavljala, da pokrajin in $\mathrm{s}$ tem tudi regionalizacije Slovenije ne bo. Tako se je tudi zgodilo. Dobili smo občine, ne 


\section{Janez Šmidovnik \\ Pokrajine dobivajo ustavne temelje}

pa pokrajin in pri tem je ostalo. Občine so začele poslovati, o pokrajinah pa smo govorili brez konca in kraja vse do današnjega dne.

Vendar je bilo $\vee$ praksi čedalje bolj jasno, da pri tem ne bo moglo ostati. Vakuum $\vee$ vmesnem prostoru med državo in občinami je bil čedalje večji in čedalje bolj očiten. Notranji razvoj Slovenije pa tudi odnosi Slovenije z Evropsko skupnostjo so pokazali, da Slovenija ne bo mogla za stalno brez institucionalizirane teritorialne ravni, ki je $v$ vseh državah najzanimivejši prostor $z$ vidika organizacije in delovanja države in njene javne uprave, obenem pa tudi oporišče za izravnavo skladnega regionalnega razvoja države. Težave pri izvajanju nekaterih neobhodnih dejavnosti $v$ vmesnem prostoru in težave $v$ zvezi z usklajevanjem regionalnega razvoja Slovenije so postajale večje kakor pa strahovi pred neznano institucijo, ki naj bi jo vzpostavili za reševanje teh težav.

\section{2.}

Formalno je bil osnova za pripravo kompromisnega predloga besedila za spremembo navedenih ustavnih členov predlog poslanske skupine LDS, ki je bil vložen v Državnem zboru 20.6.2005. Pri predhodnih obravnavah tega predloga $\vee$ poslanskih skupinah s predsednikom Ustavne komisije so se problematizirala vsa tista vprašanja, ki so se kazala kot sporna že $v$ prejšnjem ustavnorevizijskem postopku; nanašala pa so se $v$ prvi vrsti na vlogo občin pri oblikovanju in ustanavljanju pokrajin in na vprašanje potrebnega kvoruma za sprejem zakona o ustanovitvi pokrajin in drugih zakonov, s katerimi bi se urejala vprašanja pokrajin. Predlagani pravici občin, da dajejo $k$ predlogu zakona $o$ ustanovitvi pokrajin le svoja mnenja, je bila postavljena nasproti zahteva o pravici občin, da dajo k temu zakonu svoja soglasja; za sprejem zakona naj bi bilo potrebno soglasje najmanj dveh tretjin občin, na območju katerih živi najmanj dve tretjini prebivalcev predvidene pokrajine. Obveljal je kompromisni predlog (strokovne skupine), da naj se kot ustavno načelo postavi le določba, da mora biti v postopku za sprejem zakona o ustanovitvi pokrajin zagotovljeno sodelovanje občin. Sodelovanje zahteva več kot zgolj dajanje mnenj, je pa manj kot soglasje občin, ki bi utegnilo preprečiti vsak poskus za ustanavljanje občin. Konkretne oblike sodelovanja občin bodo predpisane $v$ sistemskem zakonu o pokrajinah; tak zakon je že $\vee$ pripravi. $S$ predlagano formulacijo je bil storjen velik korak v smeri kompromisa med strankami, ki je pripomogel tudi do kompromisa glede določitve kvoruma za sprejem zakonodaje o pokrajinah. Obveljala je zgolj zahteva za posebni kvorum glede zakona o ustanovitvi pokrajin; za njegov sprejem bi moralo glasovati najmanj dve tretjini navzočih poslancev Državnega zbora. Vsa druga zakonodaja, kot je npr. Zakon o financiranju pokrajin, posamezni zakoni, s katerimi bi se določale pristojnosti pokrajin in tudi sis- 


\section{Janez Šmidovnik \\ Pokrajine dobivajo ustavne temelje}

temski Zakon o pokrajinah naj bi se sprejemali z običajno večino glasov. Posebni kvorum za ustanovitev pokrajin naj bi zagotavljal visoko stopnjo soglasja v Državnem zboru glede oblikovanja pokrajin, kar je eno od najbolj delikatnih vprašanj $\vee$ zvezi z ustanavljanjem pokrajin $v$ deželi, $v$ kateri nikoli ni bilo pokrajin. Kvalificirani kvorum za sprejemanje tega zakona in pa zagotovljeno sodelovanje občin pri oblikovanju pokrajin naj bi zagotavljala dolgoročno stabilnost postavljene mreže pokrajin in maksimalno usklajenost stališč glede njihovega oblikovanja, ki je $v$ Sloveniji tudi zaradi njene geografske raznolikosti objektivno težaven problem.

S tem kompromisom, ki je postal vsebina drugega odstavka predlaganega novega besedila 143. člena ustave, pa so bile odstranjene tudi najbolj sporne točke, ki so doslej preprečevale vsak sporazum glede pokrajin. Kajti vse druge določbe predlagane nove formulacije 143. člena' so bile dejansko prevzete iz prejšnjih predlogov. Tako je s formulacijo prvega odstavka predlaganega novega besedila, ki opredeljuje pokrajino statusno kot samoupravno lokalno skupnost in njena delovna področja oziroma kategorije njenih nalog. Tu ni več nobenega slepomišenja z medobčinskim sodelovanjem. Pokrajina ni niti občinska niti državna formacija. Gre za čisto obliko lokalne skupnosti na drugem nivoju lokalne samouprave $v$ vmesnem prostoru med državo in občinami. Pokrajine ne bodo občinam niti nadrejene niti podrejene. Pokrajine in občine so si $\vee$ paralelnem, torej docela enakem odnosu z državo. Pokrajina torej ne bo mogla izvajati kakšnega nadzorstva nad občinami, pač pa jim bo morala nuditi strokovno pomoč in sodelovanje pri opravljanju njihovih nalog. Po drugi strani pokrajina tudi ne bo t.i. dvoživka, kar bi bila, če bi bila po eni strani lokalna samoupravna skupnost, po drugi strani pa tudi del državne organizacije. Kolikor bo pokrajina opravljala naloge za državo kot prenesene naloge, jih bo opravljala ne kot del države, pač pa kot lokalna samoupravna skupnost, vendar po posebnem režimu nadzorstva. Zato tudi ne bi bilo prav, če bi se npr. z zakonom o pokrajinah določala kakršnakoli pooblastila države glede imenovanja oziroma vpliva na imenovanje organov oziroma funkcionarjev $v$ samoupravnih pokrajinah. Uvajanje kakršnih koli elementov dvoživke $v$ naš sistem ne bi imelo nobene podlage, ker zato ne obstoje nikakršni zgodovinski razlogi, kakršni obstajajo npr. $\vee$ nekaterih evropskih ureditvah (npr. $\vee$ francoski ali $\vee$ nemški ureditvi),

1 Predlog za novo besedilo 143. člena: $V$ 143. členu se naslov člena spremeni tako, da se glasi: "Pokrajina».

Besedilo 143. člena se spremeni tako, da se glasi: "Pokrajina je samoupravna lokalna skupnost, ki opravlja lokalne zadeve širšega pomena in z zakonom določene zadeve regionalnega pomena. Pokrajine se ustanovijo z zakonom, s katerim se določi tudi njihovo območje, sedež in ime. Zakon sprejme državni zbor z dvotretjinsko večino glasov navzočih poslancev. $V$ postopku za sprejem zakona mora biti zagotovljeno sodelovanje občin. Država z zakonom prenese na pokrajine opravljanje posameznih nalog iz državne pristojnosti, mora pa jim za to zagotoviti potrebna sredstva." 


\section{Janez Šmidovnik \\ Pokrajine dobivajo ustavne temelje}

zlasti če upoštevamo, da se tudi $v$ teh evropskih ureditvah elementi dvoživke ukinjajo in vzpostavljajo čisti odnosi med državo in lokalnimi skupnostmi, ki delujejo v svoji avtonomnosti tudi pri izvajanju državnih nalog.

Pokrajine bodo opravljale naloge na treh delovnih področjih oziroma $v$ treh kategorijah, ki so odraz njihovega vmesnega položaja med državo in občinami: to so najprej naloge širšega lokalnega pomena, ki presegajo zmogljivosti občin, dalje so to naloge regionalnega pomena, ki bodo določene z zakoni in tretjič so to naloge iz državne pristojnosti, ki jim bodo z zakonom dane $v$ opravljanje. Naloge širšega lokalnega pomena so izvirne naloge pokrajin in si jih bodo pokrajine lahko določale same, lahko pa jim jih bo določala tudi država z zakonom. S temi nalogami bodo pokrajine najožje povezane z občinami. To področje bo moralo biti predmet stalnega sodelovanja in dogovarjanja med pokrajinami in občinami glede tega, katere naprave, službe oziroma dejavnosti bo treba vzpostaviti na nivoju pokrajine in katere na nivoju občin.

Med nalogami regionalnega pomena bodo vsekakor najvažnejše tiste naloge, ki so že rezervirane za pokrajine po Zakonu o spodbujanju skladnega regionalnega razvoja (Uradni list RS, št. 93/05), ker po 71. členu tega zakona funkcijo razvojnih regij po ustanovitvi pokrajin prevzamejo pokrajine. To pomeni, da bodo osrednji mehanizem za spodbujanje skladnega regionalnega razvoja prevzele pokrajine, s čimer bo dobil ta mehanizem, ki je bil doslej bolj ali manj v zraku, svojo pravo in čvrsto osnovo in svoje institucionalizirane nosilce za oblikovanje in izvajanje regionalne politike razvoja Slovenije. Pomembne naloge čakajo pokrajine zlasti tudi $\vee$ sferi prostorskega planiranja in varstva okolja. Razen tega imamo že po sedanji zakonodaji vrsto institucij in naprav regionalnega pomena, ki nimajo institucionaliziranega nosilca in se le s težavo opravljajo bodisi z nivoja države bodisi z nivoja občin (regionalne bolnice, regionalne ceste, arhivi regionalnega pomena, javni zavodi na področju kulture itd.). Tudi te institucije bodo s pokrajinami lahko dobile svoje institucionalne nosilce in $\mathrm{s}$ tem solidno oporo za svoje poslovanje.

Na poseben način bodo pokrajine povezane z državo z nalogami, ki jim bodo z zakonom prenesene $v$ izvajanje, kar se bo predvidoma zgodilo $s$ številnimi nalogami, ki se sedaj opravljajo $v$ upravnih enotah. $V$ tem prostoru bo prišlo zaradi tega do nove razmejitve nalog med državo in lokalno samoupravo, kar bo povzročilo tudi novo organizacijo državne uprave na terenu. Tu bo šlo za delikatno operacijo, ki ne bo brez nevarnosti, da ne bi zaradi pretiravanja v eno ali drugo smer dušila po eni strani novo nastajajočo samoupravo, po drugi strani pa kvalitetno izvajanje državne uprave v pokrajinah.

$\mathrm{Ne}$ da bi se spuščali $\vee$ podrobnosti, ki bodo stvar na tej ustavi temelječe zakonodaje, lahko ugotavljamo, da bodo naše pokrajine, podobno kot analogne teritorialne skupnosti $v$ drugih državah - postale sčasoma glavno oporišče javne 


\section{Janez Šmidovnik \\ Pokrajine dobivajo ustavne temelje}

uprave na terenu, ker bodo glede na svoje zmogljivosti lahko prevzele $v$ izvajanje vse tiste javne naloge, za katere so občine premajhne, država pa prevelika.

\section{3.}

V zvezi s takim konceptom pokrajine po predlaganem novem 143. členu so predlagane tudi spremembe 121. člena ${ }^{2}$ in drugega odstavka 140. člena ${ }^{3}$ ustave. V 121. členu naj bi se črtal prvi odstavek, ki določa, da naloge uprave opravljajo neposredno ministrstva; drugi odstavek pa bi se spremenil tako, da bi se bolj na splošno opredelili subjekti, ki lahko dobijo javno pooblastilo za opravljanje nalog državne uprave ter da bi se ta pooblastila lahko dajala ne samo neposredno z zakonom, pač pa tudi z drugim aktom na podlagi zakona. Določbe o javnem pooblastilu pravzaprav nimajo nobene zveze s pokrajinami, spreminjajo se zato, ker so $v$ istem členu (121. člen), ki se spreminja zaradi pokrajin; njihov namen je olajšati dajanje javnih pooblastil $\vee$ skladu $s$ trendom družbenega razvoja, ko vstopajo $v$ javni sektor čedalje bolj t.i. nevladne organizacije, ki potrebujejo tudi javna pooblastila. Če bi se izkazalo za neizvedljivo, da bi nosilce javnega pooblastila neposredno določil zakon, bo na podlagi nove ureditve zadoščalo, da bo zakon uredil način njihove določitve, pri čemer bo moral določiti predvsem pogoje, ki jih mora izpolnjevati vsak nosilec javnega pooblastila, organ, ki podeli javno pooblastilo in postopek za podelitev javnega pooblastila.

Določbo o ministrstvih je treba črtati, ker ne ustreza naši ureditvi (in tudi ne drugim državnim ureditvam) in pomeni oviro za vsak prenos državnih nalog $\checkmark$ izvajanje na lokalne skupnosti in na druge organizacije ter s tem seveda tudi na pokrajine. Za lokalne skupnosti (občine in pokrajine) naj bi veljale sicer izrecne določbe drugega odstavka 140. člena, po katerem lahko država - po predhodnem soglasju občine ali širše lokalne skupnosti - prenese nanje opravljanje posameznih nalog iz svoje pristojnosti, če jim za to zagotovi tudi sredstva; vendar se je ta določba $v$ praksi izkazala kot prohibitivna in zato do teh prenosov sploh ni prihajalo. Predhodno iskanje soglasja za prenos je prevelika ovira, da bi do prenosa sploh lahko prišlo. Zato je treba to določbo spremeniti, ker je treba odpreti pot za prenos državnih nalog - $v$ prvi vrsti na pokrajine, načeloma pa tudi na občine oziroma na posamezne vrste občin (npr. na večje občine). S tem

2 Predlog za novo besedilo 121. člena: $V$ 121. členu se naslov člena spremeni tako, da se glasi: "(javno pooblastilo)«. Prvi odstavek se črta. Drugi odstavek se spremeni tako, da se glasi: "Z zakonom ali na njegovi podlagi lahko pravne in fizične osebe dobijo javno pooblastilo za opravljanje določenih nalog državne uprave."

3 Predlog za novo besedilo drugega odstavka 140. člena: V 140. členu se drugi odstavek spremeni tako, da se glasi: "Država lahko z zakonom prenese na občine opravljanje posameznih nalog iz državne pristojnosti, če za to zagotovi tudi potrebna sredstva." 


\section{Janez Šmidovnik \\ Pokrajine dobivajo ustavne temelje}

bodo tudi pri nas odprte poti za uveljavljanje načela subsidiarnosti, ki se spričo obstoječe ustavne ureditve doslej ni moglo uveljavljati.

Prof. dr. Janez Šmidovnik je eden vodilnih poznavalcev in snovalcev lokalne samouprave $\checkmark$ Sloveniji. Je eden redkih, katerega desetletja stare ocene o komunalnem sistemu ostajajo aktualne še danes. Leta 1995 je v ugledni zbirki Cankarjeve založbe Pravna obzorja izdal knjigo Lokalna samouprava, ki je še dandanes temeljna učna literatura številnim študentom. V svoji bogati akademski karieri je napisal več kot 100 znanstvenih in strokovnih člankov. Leta 2001 je ob svoji 80-letnici za zasluge pri izgradnji pravnega sistema Republike Slovenije, posebej na področju državne in javne uprave ter lokalne samouprave, prejel Srebrni častni znak svobode Republike Slovenije. 
Janez Šmidovnik

Pokrajine dobivajo ustavne temelje

\section{Regions are Gaining Constitutional Bases}

1.

It would not be an exaggeration to say that the decision of the National Assembly Constitutional Commission of 12 April this year to propose a "compromise text" of the political parties to the National Assembly for the initiation of the procedure to amend Articles 121, 140 and 143 of the Constitution, which was supported by the signatures of 72 deputies of the National Assembly, represents a real historical shift in the development of the Slovenian state and its local self-government. This statement is justified for several reasons:

1. The discussion on the regions included in the above proposal has lasted more or less intensively throughout the entire period following the establishment of the municipalities in 1994 - i.e. over twelve years - and the first proposal to amend Article 143 of the Constitution was submitted to the National Assembly back in 1999 (i.e. the proposal of 33 deputies headed by Dr. Ribičič), the second proposal to amend the above three articles was presented in 2001 (i.e. proposal of the government together with other proposals from the previous constitutional revision procedure) and the third proposal of the LDS (Liberal Democracy of Slovenia) parliamentary group was submitted in 2005 (i.e. the proposal of a group of deputies signed first by Darja Lavtižar Bebler).

2. There were considerable differences of opinion voiced in the discussions on those proposals leading to diametrically opposed positions on what should be done regarding the regions and the so-called regionalisation of Slovenia, which did not produce any points in common.

3. The above proposal for the initiation of the constitutional amendment entails a decision which will, if adopted, give rise to some important reforms within the existing local self-government system as well as within the general state mechanism of the Republic of Slovenia.

Until very recently it seemed there were near insurmountable differences in opinion on whether any constitutional amendments were necessary in order to establish regions, and, if so, what those amendments should be. However, it should be noted that although no voice came out loudly against the regions-scheme it was not difficult to surmise that the "defenders" of the valid constitution were actually those who were 
against the regionalisation of Slovenia or who perceived regions merely as some kind of extensions of the municipalities.

Of course those differences arose at the political level. As far as the professional public is concerned, there were some voices at the outset wondering whether the regions could be established on the basis of the present wording of Article 143 of the Constitution. However, those voices fell silent once the preparation of the act on regions and some concrete decisions of individual municipal councils on the establishment of regions in some parts of Slovenia showed that the present constitutional wording, stating in the introductory sentence of article 143 that "Municipalities may independently decide to join into wider self-governing local communities, ..." does not enable the establishment of regions, at least not the regions with the status of a self-governing local community which would be - as municipalities are - ensured independent functioning. Not only theory but practice too has shown that regions can not be established by merely joining municipalities nor can they thus gain the status of self-governing local communities with the necessary elements (functional, territorial, organisational, material, financial and legal) of self-government. An intermunicipal integration process can only include the neighbouring municipalities and cover only individual issues of specific interest to those municipalities. However, regions should span the entire state - just like the municipalities - and enjoy the same legal status and the same duties throughout the state; otherwise general chaos would ensue. Such status can only be ensured by the state through the constitution and law, as it did in the case of municipalities with the Constitution and the Local SelfGovernment Act.

It would, therefore, be necessary to amend the Constitution in order to establish regions. Even before the adoption of the Constitution, when I was surprised by the text of Article 143 of the final draft of the Constitution which was formulated at the last minute before the adoption of the Constitution, I wrote in "Naši razgledi" that without the constitutional amendment, there would be no regions. At that time I was told that the formulation of Article 143 represented a compromise political solution which enabled the inclusion in the Constitution of Article 55 on the freedom of choice in childbearing which also provides for abortion. In truth, the contradictory formulation of Article 143 was largely a compromise between those favouring strong decentralisation of the state through local self-government on the one hand, and the centralists, who promoted the 
Janez Šmidovnik

Pokrajine dobivajo ustavne temelje

central administration of Slovenia together with weak decentralisation through local communities on the other, since they feared that those communities might dissolve the state of Slovenia before it could be consolidated into a solid national community. Such wording of Article 143 apparently suited both - those who were in favour of stronger decentralisation of the state by promising them a two-stage local self-government or the regionalisation of Slovenia, and the centralists, with the provisions on the freedom to form regional alliances while at the same time ensuring that there would be no regionalisation of Slovenia. Which is what eventually happened. The municipalities were established but not the regions. The municipalities began operating while the regions have been the subject of endless discussions which continue to this day.

However, in practice it has become increasingly clear that this situation can not last. The vacuum in the space between the state and the municipalities has been growing larger and more obvious. Slovenia's internal development as well as its relations with the European Union have shown that it will not be able to keep up without the institutionalised territorial level which is, in other states, the most interesting level from the point of view of the organisation and the functioning of the state and its public administration, and serves as a foothold to ensure balanced regional development. Eventually the problems of realising some important activities in the space between the state and the municipalities and the difficulties related to harmonising regional development of Slovenia became greater than the fear of the unknown institution which should be established in order to resolve those problems.

2.

Formally, the basis for the preparation of the compromise proposal of the text for the amendment of the above Articles of the Constitution was proposed by the LDS parliamentary group and submitted to the National Assembly on 20 June 2005. During the preliminary discussions of the proposal within the parliamentary groups with the president of the Constitutional Commission, special attention was paid to all those questions which proved problematic already during the previous constitutional revision procedure: primarily the questions regarding the role of municipalities in the formation and establishment of regions as well as regarding the necessary quorum for the adoption of the act on the establishment of regions and other acts which would resolve the issue of regions. The pro- 
posed right of the municipalities only to submit their opinions on the proposal of the act on the establishment of regions was juxtaposed by the demand for the right of municipalities to grant their consent to that act. For the adoption of the act, consent should be given by at least two-thirds of the municipalities in the territory, of which at least two-thirds of the inhabitants of the region concerned live. Eventually the compromise proposal (of the expert group) prevailed, according to which the constitution should contain only the provision stating that the co-operation of municipalities must be ensured in the procedure for the adoption of the act on the establishment of regions. Such co-operation requires more than the mere offering of opinions, but still less than granting consent which might prevent any attempt to establish regions. Concrete forms of co-operation for the municipalities will be laid down in the fundamental act on regions which is already in the process of preparation. The proposed wording represents an important step in the direction of compromise between the parties which also contributed to the compromise regarding the determination of the quorum for the adoption of the legislation on regions. A special quorum was laid down only for the act on the establishment of regions, the adoption of which requires the votes of at least two-thirds of the present deputies of the National Assembly. All other legislation, such as the act on the financing of regions, individual acts laying down the competencies of regions and the fundamental act on regions, would be adopted by a simple majority of votes. A special quorum for the establishment of regions should enable a high level of consent in the National Assembly regarding the formation of regions, which is one of the most delicate questions related to the establishment of regions in a state where no regions have ever existed before. The qualified quorum for the adoption of the act and the ensured co-operation of municipalities in the formation of regions should enable long-term stability of the established network of regions as well as the maximum reconciliation of viewpoints regarding their formation, which objectively represents a difficult problem in Slovenia due to its geographical diversity.

This compromise, which came to form the content of the second paragraph of the proposed new text of Article 143 of the Constitution, would remove the most controversial issues which have, until now, prevented any kind of agreement regarding the regions. All other provisions 
Janez Šmidovnik

\section{Pokrajine dobivajo ustavne temelje}

of the proposed new text of article $143^{1}$ have actually been brought over from previous proposals. Thus the first paragraph of the proposed new text defines a region in terms of its status as a self-governing local community and determines its areas of work or categories of its duties. Any dissembling as concerns inter-municipal co-operation has been eliminated. The region is neither a municipal nor a state body. It is a pure form of local community at the second level of local self-government, present in the space between the state and the municipalities. Regions will be neither superior nor inferior to municipalities. They both exist in a parallel, i.e. completely equal, relation to the state. Thus a region will not be able to carry out any control over municipalities. Instead it will have to offer them professional assistance and co-operation in carrying out their duties. A region will not have a dual character, which would be the case if it were a local self-governing community on the one hand and a part of the state administration on the other hand. If a region carries out vested duties for the state, it will carry them out in its capacity not as a part of the state but as a local self-governing community under a special supervision regime. It would, therefore, be inappropriate to use e.g. the act on regions, in order to lay down any state powers regarding the appointment or influence on the appointment of bodies or officials in self-governing regions. There would be no justification for introducing any dualistic elements into the Slovenian system, since there exists no historical precedent for that which can be found in some European regimes (as in France and Germany). It should be noted that even in those European regimes these dualistic elements are being abolished and clear relations between the state and local communities introduced based on principles of autonomy - also in its carrying out of state duties.

The duties to be carried out by regions can be divided into three fields of work or categories reflecting their intermediate position between the state and municipalities: firstly, the duties of wider local importance which surpass the capacities of municipalities; secondly, the duties of

1 The proposal for the new text of Article 143: The title of Article 143 shall be amended as follows: "Region". The text of Article 143 shall be amended as follows: "The region is a selfgoverning local community which deals with local issues of wider importance and issues of regional importance laid down by law. Regions are established with an act which shall also lay down their territory, seat and name. The act shall be adopted by the National Assembly with a two-thirds majority of votes of the present deputies. The co-operation of municipalities shall be ensured in the procedure of adopting the act. The state shall vest in regions specific duties from the state competence by law and provide the necessary financial resources for carrying out those duties." 
regional importance which will be laid down by laws; and thirdly, those duties from the state competence with which they will be vested by law. The duties of wider local importance are the original duties of regions, so they will be determined by the regions on their own or by the state according to law. Those regions will have closest ties with the municipalities through those duties. This area will have to be the subject of constant cooperation and consultation between regions and municipalities on which facilities, services or activities will have to be established at the regional or municipal levels.

From among the duties of regional importance priority will be given to those which have already been allocated to regions in accordance with the Promotion of Balanced Regional Development Act (Official Gazette of the Republic of Slovenia, No. 93/05) since pursuant to Article 71 of that Act, the function of developing regions will be taken over by regions once they are established. This means that the central mechanism for encouraging balanced regional development will be assumed by regions, which will enable this mechanism - which has been more or less undefined until now - to gain a sound basis and the institutionalised holders for forming and implementing Slovenia's regional development policy. Regions will also have to deal with some important duties in the area of physical planning and environmental protection. Moreover, the present legislation already lays down a number of institutions and facilities of regional importance which do not have an institutionalised holder and are very difficult to carry out at either the state level or at the municipal level (regional hospitals, regional roads, archives of regional importance, public institutes in the field of culture etc.). With the establishment of regions, those institutions will gain their institutional holders and thus a sound basis for their activities.

Regions will be linked to the state in a special way through the duties vested in them by law, which are envisaged to be the numerous duties which are now carried out by administrative units. Therefore, a new division of duties between the state and local self-government will have to be carried out, which will lead to a new organisation of state administration in the field. This will be a delicate project which might, due to overzealousness in one direction or the other, stifle, on the one hand, the newly established self-government and, on the other hand, a quality realisation of state administration in regions. 
Janez Šmidovnik

Pokrajine dobivajo ustavne temelje

Leaving the details to the legislation which will be adopted on the basis of this Constitution we can conclude that Slovenia's regions will, similarly as analogous territorial communities in other states, gradually become the main foothold of public administration in the field since, thanks to their capacities, they will be able to take over all those duties for which the municipalities are too small and the state too large.

3.

The above concept of the region laid down in the new Article 143 has also led to the amendments of Article $121^{2}$ and the second paragraph of Article $140^{3}$ of the Constitution. In Article 121 the first paragraph laying down that the duties of the state administration are performed directly by the ministries is to be deleted, and the second paragraph is to be amended by defining, in general, the entities which may be vested with public authority for the performing of the duties of the state administration, whereby those powers may be vested not only directly by law but also by other legislative acts on the basis of the law. The provisions on public authority are actually not related in any way to the regions but are amended since they appear in the same Article (121) which is to be amended with regard to regions. Their aim is to facilitate the vesting of public authorities in accordance with the trends in social development where the so-called NGOs, which also require public authorities, are increasingly entering the public sector. If it does not prove feasible to determine the public authority holders directly by law, the new regulation will provide for the possibility that the law regulates the manner of their appointment by laying down the conditions to be fulfilled by each public authority holder, the body vesting public authority and the procedure for vesting public authority.

The provision on the ministries is to be deleted since it does not comply with the Slovenian system (nor with other state systems) and represents a barrier to any vesting of state duties in local communities and

2 The proposal for the new text of Article 121: The title of Article 121 shall be amended as follows: "(Public Authority)". The first paragraph shall be deleted. The second paragraph shall be amended as follows: "The legal and natural persons may be vested by law or on its basis with public authority to perform certain duties of the state administration."

3 The proposal for the new text of the second paragraph of Article 140: The second paragraph of Article 140 shall be amended as follows: "The state may vest specific duties within the state jurisdiction in the municipalities by law, if it provides the necessary financial resources for this purpose." 
other organisations including regions. Local communities (municipalities and regions) are to be the subject of explicit provisions of the second paragraph of Article 140 according to which the state shall - after prior approval of the municipality or wider local community - assign them individual duties from its jurisdiction if it provides the necessary financial resources. However, in practice this provision has proven to be prohibitive and therefore no such assignment has been effected. Prior obtaining of consent, which is the precondition for such assigning procedures proved an insurmountable obstacle. This provision should be amended in order to enable the vesting of state duties - primarily in regions and also in municipalities or various types of municipalities (e.g. large municipalities). This will also enable the implementation of the principle of subsidiarity in Slovenia which could not be implemented until now due to the existing constitutional regime. 